\title{
Counter-Terrorism in the EU's External Relations
}

\author{
Mai’a K. Davis Cross
}

\begin{abstract}
The renewed emphasis on national political boundaries across Europe would seem to go hand-inhand with a weaker external personality for the EU. However, there are several prominent examples of EU leadership that challenge this notion, from the December 2015 UN climate change agreement to common sanctions against Russia to a new Global Strategy. This paper examines a policy area that lies at the intersection of populist outrage and external engagement: counter-terrorism. In the wake of the 2015 and 2016 Paris and Brussels terrorist attacks, the EU has made significant strides in enhancing the external dimension of its counter-terrorism policies, particularly in terms of intelligence sharing, formal and informal diplomacy, and the internalexternal nexus of security. The article argues that major terrorist attacks in 2015-2016 have served as critical junctures of crisis, driving counter-terrorism policies forward and emphasizing the notion of European boundaries beyond any functionalist or securitization explanation.
\end{abstract}

Keywords: terrorism, counter-terrorism, EU foreign policy, EU crises, EU integration

\section{Introduction}


The renewed emphasis on national political boundaries across Europe in the second decade of the $21^{\text {st }}$ century would seem to go hand-in-hand with a weaker external personality for the EU, as several contributions to this special issue contend (Bellamy and Kröger this issue; Zielonka this issue). However, there are many prominent examples that defy this argument. The EU emerged as the leader in marshaling an ambitious agreement at the UN climate summit in Paris, COP21 (Torney and Cross forthcoming). It has strengthened its relationship with NATO, at the same time as collectively imposing a wide-ranging sanctions regime against Russia (Cross and Karolewski 2016). And it has stood strong in the face of Brexit, even releasing a new Global Strategy and advancing plans for a defense union just days after the referendum (Tocci 2016, Cross 2016). Despite growing voices in some sectors calling for the re-assertion of national political boundaries, I argue that European political boundaries vis-à-vis the outside world are actually becoming stronger. How is the EU able to continue its march towards "ever closer Union" in its external relations while grappling with numerous challenges to integration internally?

This special issue understands political boundaries as "those lines of demarcation enforced by a political authority that affect agents' range of options in producing and accessing goods widely understood to be desirable for them in the pursuit of their respective goals." EU integration has fundamentally been about a process that increasingly strengthens the notion of European boundaries over time, especially in terms of political authority, in multiple ways. To address the question of how European political boundaries are getting stronger in terms of external relations, this article focuses on the policy area of counter-terrorism. In the wake of the 2015 and 2016 Da'esh-inspired terrorist attacks in Paris and Brussels, the EU has made 
significant efforts to enhance counter-terrorism agreements across member states and with third countries, especially in intelligence sharing, formal and informal diplomacy, and the internalexternal nexus of security.

However, there is a fundamental tension in these efforts that has led to a crisis - one of several - for EU integration. On the one hand, it makes sense for the EU to act as one in this area through combining resources and opening up flows of information with third-country allies. On the other hand, the EU's growing terrorist threat is also fueling nationalist groups at home (such as, Alternative for Germany, France's National Front, the Dutch Party for Freedom, Greece's Golden Dawn, Hungary's Jobbik, Sweden Democrats, Austria's Freedom Party, and People's Party-Our Slovakia) who fear outsiders, particularly Muslim migrants from the Middle East, and want to close national borders in the name of security. Consequently, at the same time that EU institutions are pushing for integrated approaches to counter-terrorism policy, far-right parties within member states are calling for the closing of national borders in response to attacks. For the latter, declaring a "state of emergency" is fundamentally about re-asserting and strengthening national boundaries instead of European ones. While it is clear that reinstating national boundaries is no solution to the threat, the clash of these opposing ideas is intimately tied to the very meaning of political boundaries for security.

In light of these new threats, and the tensions they produce, how is the EU shaping its boundaries in the realm of counter-terrorism vis-à-vis external actors? What are the driving forces of change? And what bearing does this have on the meaning of European boundaries more generally? I argue that despite a palpable turn to nationalism among some groups within, 
the EU's external legal personality - now primarily expressed through the European External Action Service (EEAS) - is actually becoming more robust and coherent in tangible ways, with the launch of numerous new policies in reaction to the 2015 and 2016 terrorist attacks. As will be shown in this article, the EU is using each major terrorist attack as an opportunity to justify decisions that strengthen the EU's role in this policy area. Indeed, in the wake of each attack, we can observe the adoption or acceleration of new external policies.

In the following sections, I first outline how functionalism or securitization theory would explain the strengthening of European boundaries in the field of counter-terrorism, and argue that the best explanation is actually a crisis-driven approach. Decision-makers treat the attacks as moments of crisis that justify a strengthening of European boundaries. In the second section, I then turn to the specific empirical evidence demonstrating that the EU, particularly through the EEAS, has responded to terrorist threats by asserting European boundaries in the external realm. Finally, given that these new counter-terrorism policies rest on renewed emphasis on common rather than national boundaries, and occur under emergency conditions, I consider the extent to which these developments are legitimate.

\section{Why a strengthening of European boundaries?}

When it comes to counter-terrorism, European political boundaries have been strengthening for some time. In the wake of the $9 / 11$ attacks a number of policy areas rapidly moved forward in what had previously been the third pillar of the Maastricht Treaty (Vries 2016, Argomaniz, Bures, and Kaunert 2015, Monar 2015, Cross 2011). For example, in 2002, the European Arrest Warrant was launched, after the 2004 attack in Madrid, the position of Anti- 
terrorism Coordinator was created, and in the wake of the 2005 London attack, the EU CounterTerrorism Strategy was signed, among many other things. Indeed, in the period between 2001 and 2015, 239 measures to combat terrorism were agreed at the European level (Aftenposten 2015). I argue that there is a pattern in which after each major terrorist attack in Europe, more decisions have been made to strengthen common boundaries. The recent attacks in 2015 and 2016 have spurred on even more wide-ranging decisions in this area, as will be discussed in the next section. Before getting to this evidence, and what it means for European boundaries, it is necessary to consider various explanations for why the EU is reacting this way in the field of counter-terrorism. What are the mechanisms behind responding to terrorist threats with more integration?

A functionalist approach would contend that it is simply in the self-interest of member states to work together to prevent terrorism. According to the theory, if a serious threat emerges, member states must deal with it, and they will strive to do so efficiently. As David Mitrany (1966) argues, integration occurs as member states create institutions to "meet needs as they arise." The problem with this explanation on its own is that self-interest could be interpreted as leading either to re-asserting national boundaries or strengthening European ones, depending on how one evaluates the situation. While security experts argue unequivocally that the EU is stronger working together on terrorism, for others, it is not entirely clear whether national or European boundaries provide the solution, particularly considering that over five thousand of the EU's own citizens are radicalized or returning foreign fighters. Among some societal sectors, there have been widespread calls for closing national borders, and instituting states of emergency. This theoretical approach tells us little about why member states would choose one 
over another when the particular policy field is contested or more complex. Moreover, as Occhipinti (2015) and Argomaniz (2015) argue institutions working at the European level in the counter-terrorism area tend to be path-dependent in the type of approach they pursue over time, which generally has entailed emphasizing a stronger European dimension.

In contrast to functionalism, securitization theory accounts for how one views the threat. This approach argues that if something is perceived as a security threat then it will be treated as such, but that the very same issue could just as easily be perceived and treated differently (Buzan et al. 1988; Wæver 2011; Taurec 2006; Stritzel 2007). Thus, as Thierry Balzacq (2011, preface) writes, "the social design of a security problem conditions and legitimates the kind of means used to stop it." From this perspective, the strengthening of European boundaries can be understood as a result of narratives about terrorism that have raised the stakes over time. Securitization theory focuses on how shared knowledge, myth, language, or practice construct policies to respond to a threat (Léonard 2010). One argument from this school of thought is that terrorism has been talked about and treated as a much more serious and imminent threat to security than it is in reality. John Mueller (2006) argues that ever since 9/11, the perceived threat from terrorism in the US has been vastly overblown. The same has been said of Europe. Thus, by this account, the strengthening of European boundaries in its external quest to fight terrorism is a product of overreaction, and even panic.

Another major line of reasoning in the securitization literature involves the relationship between migration and terrorism. Many scholars from this school of thought find that migration has been securitized in Europe, and can be connected to certain counter-terrorism measures, such 
as the creation and design of FRONTEX (Léonard 2010; Huysmans 2006; d'Appollonia and Reich 2008; Colman 2006). The strengthening of European boundaries in this regard can be traced back to post-colonial migration flows to Europe in the 1950s-70s. In basic terms, migrants came to Europe to seek a better life, and were welcomed because there was a labor shortage. However, in the longer-term, social assimilation was difficult, and eventually led to some anti-immigrant, nationalist sentiments. Fast-forward to the rise of Da'esh in the $21^{\text {st }}$ century, and the radicalization of some second (or third) generation migrants has occurred prompting a more serious backlash coming from far-right nationalists. The shared memory of this history leads the EU to transform its counter-terrorism policy from a traditionally internal, policing matter to a rapidly escalating external, foreign policy matter because blaming Europe's migrants for terrorism goes against the EU's core values of openness and inclusion. The solution or response to social interpretations of terrorism becomes a drive to re-assert European norms and quell the nationalist backlash through a kind of displacement strategy, seeking to turn the public's attention away from internal causes to external threats.

If the EU is acting in this way, trying to restore "ontological security" in light of a particular type of securitization of terrorism, it could be doing so for either instrumental or normative reasons. A more instrumental approach would assume that the EU is mainly concerned with perpetuating its own existence and will construct discourses surrounding the terrorist threat that takes blame away from the EU and its principles. A more normative discourse would focus on the ideals that the EU stands for, and would acknowledge the ways in which the EU itself must struggle to overcome its own shortcomings as part and parcel of any response to terrorism. 
Securitization theory is valuable in that it recognizes that perceptions define threat. However, the problem with the approach is that it does not go far enough in accounting for the impact of crises, and the agency of particular decision-makers in the wake of these events. In other words, it does not explain why after each terrorist attack, decisions regarding the strengthening of European boundaries are arrived at more quickly and with particular characteristics. In general terms, securitization theory offers some broad insight into the gradual adoption of European polices in light of long-standing shared knowledge and understandings about what should be securitized. But it is less effective at grappling with the impact of an actual attack, when there is an immediate opening for practitioners to reconsider how to interpret and respond to threats in concrete terms.

There must be more to the dynamic besides longer-term shared knowledge and myth. Empirically, there is little evidence of policy makers using a displacement strategy to advance counter-terrorism cooperation over time. And even though the EU has been preparing to deal with terrorism since 9/11, it has proven to be unsuccessful at preventing the slew of attacks in 2015-2016. Its numerous common policies have not even been all that effective at responding once attacks are underway. Thus, the crisis lies less in the terrorist attack itself, and more in the EU's realization of the scale of the problem, the fact that it has not done enough to secure Europe's homeland, and the domestic implications in the form of resurgent nationalism in the wake of each attack.

I argue in this paper that major terrorist attacks in 2015-2016 have served as critical 
junctures of crisis, driving counter-terrorism policies forward beyond any pre-existing understanding of this as a security issue. While securitization undoubtedly occurs over the longer-term, crises are periods in which long-standing discourses and practices come into question. An oft-invoked cliché after the fact is that crises serve as opportunities, leading the EU to respond to crisis with more integration. The pattern across Europe's historical response to crisis of various sorts shows that there is more to this than the cliché implies (Cross 2017). When a crisis is perceived to be particularly severe, new dynamics often emerge within Europe, such as new levels of trust in EU institutions (Natorski and Pomorska 2016), desire for member states to stand together despite initial resistance (Orenstein and Keleman 2016), sense of common identity or rally-around-the-flag effect (i.e. us vs. them), policy innovation (Bicchi 2007; Cross 2017), political will to do more or spend more in reaction to the crisis (Schilde 2016), and so on.

Depending on the nature and severity of the crisis, each policy area may invoke different types of responses. In the case of counter-terrorism, I argue that efforts to strengthen European boundaries have occurred in reaction to the 2015-2016 attacks because each is increasingly provoking the perception of a dual crisis. First, there is the obvious crisis of the attack itself the casualties, injuries, fear, and disruption, as well as the failure of preventing and responding effectively to the threat. Second, there is the emboldening of nationalist and anti-immigrant groups in Europe, stoking a crisis of a different sort. In response to each attack, far-right nationalist parties have become noticeably more vocal and have solidified their policy rhetoric connecting anti-immigration policies to Islamophobia and hatred of the EU. This type of dangerous rhetoric, which could ultimately pose an existential threat to the EU, has also spurred on a stronger external response, increasingly evolving from softer to harder power forms of 
political authority.

Thus, the repetition of this dual crisis throughout 2015 and 2016 has reframed the EU's interests, leading it to strengthen European boundaries in the form of policy responses. It is neither enough to assume that European boundaries are the natural solution (functionalism), nor to rely on longer-term discourses about the securitization of certain issues like migration to explain this outcome. Rather, each major attack in 2015-2016 created an opening for decisionmakers to gauge the impact, reassess the nature of the policies in place, and give the green light for EU institutions to enhance the external dimension in response. Member states too were willing to give the EU more power in its external relations, despite the pull of national sovereignty, in light of these different but co-existing threats to European values. This is significant in that member states have historically not given the EU authority in this area, especially before 9/11 (Monar 2015).

\section{The Case of Counter-terrorism}

In 2015 and 2016, there were a series of major terrorist attacks in the EU. In January 2015, the offices of Charlie Hebdo, in the heart of Paris, a Jewish supermarket, and several other locations were targeted. The second Paris attack, on 13 November 2015, was the deadliest in the EU since the 2004 Madrid attack, involving coordinated attacks with suicide bombers outside of the Stade de France, a massacre at the Bataclan Theater, and several mass shootings and a suicide bomb in other locations across Paris. Then, in 22 March 2016, suicide bombings took place at the Brussels airport and Maalbeek metro station in the EU quarter of Brussels. 
Numerous other terrorist attacks occurred (or were thwarted) throughout the course of 2016, including several in Germany, France, Belgium, Austria, and Italy, all of which seemed to have been inspired by Da'esh or Al Qaeda. The focus here is on the policy responses to the January and November 2015 as well as the March 2016 attacks.

As mentioned above, these attacks gave fuel to the nationalist parties that had already been strengthening since 2010, sparking numerous comparisons to the 1930s (for example, see Palmer 2013). While each far-right party in Europe has different motivations and rationales, many of them emphasize some combination of fear and anger surrounding unemployment, austerity, immigrants, and loss of national identity to globalization. Most also have anti-Semitist or racist origins. The terrorist attacks enabled such party leaders to consolidate their platforms around Islamophobia and anti-immigration rhetoric. Through the course of this period, both France and Belgium declared states of emergency, closed their borders, and deployed their national militaries into their main cities, prompting some to ask whether the Schengen Agreement was over. Given that the November attacks occurred just weeks before the UN Climate Summit in Paris, the French government even took the extraordinary measure of forbidding any gatherings or marches to demonstrate against climate change. Thus, many core EU values were at stake as a result of the terrorist attacks: the free movement of people within the EU, the right to protest, the protection of civil liberties, and the cherished principle of using force as a last resort. For a time, the very meaning of European boundaries was profoundly destabilized.

In light of this, several European institutions acted quickly to shape new strategies, 
especially Europol internally and the EEAS externally. To be sure, the external dimension has been growing in breadth and depth at least since the 2005 Counter-Terrorism Strategy, and more recent Terrorism Action Plan. Argomaniz, Bures, and Kaunert (2015) argue that the EU has achieved a degree of external actorness in this regard. But before these initiatives, in contrast to the United States, European countries have long had the approach of addressing terrorism exclusively with internal, policing responses. To the extent that they engaged in cooperation with third-countries, it was exclusively the prerogative of individual member states (Monar 2015). In response to the November 2015 and March 2016 attacks, the EEAS - especially, the Multilateral and Global Affairs division - intensified this external dimension. Some of the EEAS's response involved accelerating the policies that had been stalled, and others involved launching entirely new policies (Council of the EU November 20, 2015; Council of the EU November 16-17, 2015). The new policies were concrete and far ranging, and their purpose and justifications were clearly centered on strengthening European boundaries in external relations, in spite of the rising tide of extreme nationalist sentiment within some member states. In particular, the EEAS advanced the internal-external nexus of security, EU-US intelligence sharing, and formal and informal diplomacy to foster cooperation with third countries, all of which are tied to the notion of boundaries, as I describe below. Moreover, the political authority associated with each of these innovations tended to move from softer forms of combatting terrorism (co-optation) to harder forms of enforcement (coercive) after each attack. Table 1 summarizes the policies that were accelerated as well as the innovations that were launched, mainly by the EEAS.

Table 1: Institutional Responses to Terrorism in the EU's External Relations 


\begin{tabular}{|c|c|c|c|c|}
\hline & $\begin{array}{l}\text { Accelerated } \\
\text { Policies in 2015- } \\
2016 \\
\end{array}$ & $\begin{array}{l}\text { New policies after } \\
\text { January } 2015 \\
\text { attacks }\end{array}$ & $\begin{array}{l}\text { New policies after } \\
\text { November } 2015 \\
\text { attacks }\end{array}$ & $\begin{array}{l}\text { New policies after } \\
\text { March } 2016 \\
\text { attacks }\end{array}$ \\
\hline $\begin{array}{l}\text { Intelligence } \\
\text { sharing }\end{array}$ & $\begin{array}{l}\text { Passenger } \\
\text { Named Record } \\
\text { Agreement; } \\
\text { information } \\
\text { sharing with the } \\
\text { US }\end{array}$ & $\begin{array}{l}\text { Information } \\
\text { sharing with } \\
\text { Turkey \& Saudi } \\
\text { Arabia; launch of } \\
\text { Europol's Counter } \\
\text { Terrorist Centre }\end{array}$ & $\begin{array}{l}\text { Approval of the } \\
\text { PNR; intelligence } \\
\text { sharing expanded } \\
\text { to include more } \\
\text { third countries }\end{array}$ & $\begin{array}{l}\text { Focus on foreign } \\
\text { fighters, especially } \\
\text { after collapse of } \\
\text { Da'esh; prevention } \\
\text { of recruitment \& } \\
\text { radicalization in } \\
\text { refugee camps }\end{array}$ \\
\hline $\begin{array}{l}\text { Internal- } \\
\text { external } \\
\text { nexus of } \\
\text { security }\end{array}$ & $\begin{array}{l}\text { Political } \\
\text { Dialogues on } \\
\text { Counter- } \\
\text { terrorism; } \\
\text { drafting of EU } \\
\text { Global Strategy }\end{array}$ & $\begin{array}{l}\text { Capacity-building } \\
\text { and sharing of best } \\
\text { practices in } 3^{\text {rd }} \\
\text { countries }\end{array}$ & $\begin{array}{l}\text { Mutual Defence } \\
\text { Clause; future } \\
\text { EDA "White Book } \\
\text { on Defense" }\end{array}$ & $\begin{array}{l}\text { EU Global } \\
\text { Strategy; proposed } \\
\text { directive making } \\
\text { "preparatory acts" } \\
\text { of terrorism illegal }\end{array}$ \\
\hline $\begin{array}{l}\text { Formal } \\
\text { diplomacy }\end{array}$ & $\begin{array}{l}\text { Counter- } \\
\text { Terrorism } \\
\text { Strategies with } \\
3^{\text {rd }} \text { countries }\end{array}$ & $\begin{array}{l}\text { Deployment of } \\
\text { security specialists } \\
\text { to EEAS } \\
\text { delegations }\end{array}$ & $\begin{array}{l}\text { New impetus in } \\
\text { Vienna talks on } \\
\text { Syria; new } \\
\text { cooperation with } \\
\text { Morocco, Syria \& } \\
\text { Iraq, and others }\end{array}$ & $\begin{array}{l}\text { Flourishing of EU } \\
\text { diplomatic efforts } \\
\text { with } 3^{\text {rd }} \text { countries; } \\
\text { elevation of } \\
\text { Turkey \& Libya as } \\
\text { priorities }\end{array}$ \\
\hline $\begin{array}{l}\text { Informal } \\
\text { diplomacy }\end{array}$ & $\begin{array}{l}\text { Global Counter- } \\
\text { terrorism Forum }\end{array}$ & $\begin{array}{l}\text { EU-level forum } \\
\text { with IT companies }\end{array}$ & $\begin{array}{l}\text { Effort to be seen as } \\
\text { a global security } \\
\text { provider }\end{array}$ & $\begin{array}{l}\text { Global Coalition to } \\
\text { counter Da'esh - } \\
\text { emphasis on } \\
\text { partnerships }\end{array}$ \\
\hline
\end{tabular}

\section{Intelligence Sharing}

Intelligence sharing relates to boundaries in a somewhat paradoxical way in that it reinforces common boundaries at the same time as opening its boundaries to third countries. It gives the EU a stronger personality externally, vis-à-vis those with whom the EU trusts to share its information. This can be thought of as a form of demoicracy, as discussed in this special issue, which includes rather than excludes outsiders (Nicolaidis and Viehoff). One of EEAS's first steps in January 2015, shortly after the Charlie Hebdo attacks, was to open up the issue of 
revamping the EU's Counter-Terrorism Policy, with a particular focus on sharing intelligence (Mogherini interview with Amanpour 2015). This received strong support from the EU's Counter-Terrorism Coordinator, Gilles de Kerchove, who called specifically for a European Passenger Name Record (PNR) directive (as had existed in the US for some time). Such a policy allows EU terrorism experts, for example, in Europol and Interpol, to actively track where people have traveled before entering the EU, and determine whether individuals raise red flags in terms of possible radicalization. At the time of the Charlie Hebdo attacks, sixteen EU countries had already implemented PNR, but there was still no EU-level framework. The European Parliament had put up obstacles to the directive, arguing that it violated civil liberties. But on 4 December 2015, just over two weeks after the November 2015 attacks, both the Council and the Parliament agreed to move forward with the EU-level agreement in the name of European security (Council of the EU December 4, 2015). This was clearly a step closer to more hard power forms of political authority, and one that had faced much resistance until the first major terrorist attacks provided an opening to re-think Europe's position on this.

Beyond PNR, the EEAS began building stronger bilateral relationships and mechanisms to share information with third countries, particularly Saudi Arabia and Turkey (EEAS February 2015). It also accelerated intelligence sharing with Algeria, Egypt, Yemen, the Gulf countries, some African nations, and the US. The EU now provides around $€ 142$ million per year to build capacity for countering terrorism in third countries (Vries 2016). As the threat to member states tangibly and visibly increased with the 13 November 2015 terrorist attacks, the EEAS launched broader discussions on how intelligence sharing could become even more comprehensive. Many more intelligence-sharing policies were immediately discussed in the wake of these attacks, such 
as the possibility of creating a CIA-like agency for Europe, and strengthening the role of IntCen, especially in the EEAS delegations. Such initiatives are ongoing, but also would have been too controversial even to enter the discussion earlier. The strengthening of these agreements with third countries has the potential to elevate the EU's actorness in external relations.

After the 2016 Brussels attacks, Eurojust and the Counter-Terrorism Coordinator added another layer, emphasizing the tracking of foreign fighters through intelligence sharing ("Fight Against Terrorism News Alerts," October 25, 2016). In particular, policies concerning how to prevent radicalization and recruitment in Europe's refugee camps were initiated, in recognition of the dangerous cycle that leads back to more Islamophobia in Europe ("Exchange of views with Gilles de Kerchove," September 26, 2016). The push to have the EU take on a bigger role in counter-terrorism was evident when the Counter-Terrorism Coordinator himself expressed a wish for his role to become redundant so that the European Commission and EEAS could handle everything related to terrorism, without the need for his position (Ibid.). In effect, after the third major attack on a European city, representatives of several EU institutions were pushing for supranationalism as a means of stopping terrorism as well as disrupting the feedback loop that was stirring up nationalist sentiments within member states. This approach of actually tracking and controlling individuals represents a ratcheting up of the hard power authority of these policy initiatives compared to before.

\section{Internal-External Nexus}

The internal-external nexus of security relates to the issue of boundaries in that it links to 
the notion of how states have access to security tools and practices. In the case of counterterrorism, member states and the EU increasingly have access to the same tools externally that they have had internally by virtue of stronger European boundaries. Federica Mogherini said, "I have said many times since the attack on Charlie Hebdo that there must be no divide between what the European Union does internally, and what we do externally, when it comes to our security" (EEAS January 14, 2015). In the wake of the January 2015 attacks, the EEAS began working with all relevant EU institutions and the member states to coordinate the EU's outreach to third countries. The EEAS's goal is to help ensure that this outreach is cohesive and efficient through Political Dialogues on Counter-Terrorism (with countries and international organizations like the UN, the US, Russia, Canada, Turkey, Pakistan, Saudi Arabia, the United Arab Emirates, and Australia), support of the UN in countering violent extremism, implementation of CounterTerrorism Action Plans, and contributions to capability-building in third countries (EEAS website on counter-terrorism). The High Representative's main message was to create strong linkages between internal and external security when it comes to counter-terrorism.

After the November 2015 attacks, the EEAS consciously broadened the ideational space for conceiving of counter-terrorism, explicitly bringing in an external dimension. At French President Hollande's request, the EU for the first time discussed activation of its Mutual Defense Clause, and received unanimous support from the member states. The use of the Mutual Defense clause represented a hard power form of political authority added on to the more soft power use of diplomacy with third countries. At the conclusion of the November 16-17, 2015 Foreign Affairs Council, Mogherini said, "France has been attacked. Europe as a whole has been attacked. Today France sought the help and assistance of all of Europe. And today Europe, 
united, responded yes" (Council of the EU November 16, 2015). In the press Q\&A session following the meeting, Mogherini said, "It is not only an attack on Europe, it is an attack on civilization - I would say - which requires us to unite forces, share information, share a political agenda, put together all of our diplomatic, economic - sometimes also military efforts - to face this threat."

Both statements demonstrated the importance of treating terrorism as located at the intersection of both internal and external approaches, and emphasized the need to approach an attack on one as an attack on all. But at the same time, in reaction to growing right-wing populism within member states, Mogherini warned, "Challenges in Syria, challenges today in France, in Europe, are common challenges: security there means security here. No confusion must be made between the issue of migration and refugees, and terrorist threats, as those who are seeking the EU's protection are escaping from the very same threat we are facing" (Foreign Affairs Council November 16-17, 2015). After the second attack in Paris, there was growing awareness of the impact this was having on public opinion in terms of associating security threats with Europe's relatively open external borders and the migration crisis. Thus, the underlying message from the EEAS was that the strengthening of European boundaries was not intended to create another layer of nationalism above the state. Rather, European boundaries in external relations meant taking a cosmopolitan, democratic, and inclusive view of the external world. In this sense, the motivation was similar to that of increased intelligence sharing in which Europeanization amplified the nature of EU demoicracy. 
In the midst of all this, EU leaders accelerated agreement on the new EU Global Strategy, which emphasizes the internal-external security nexus even further. It stipulates the goal of tackling terrorism as well as other foreign policy challenges with a firmer commitment to European boundaries. The strategy is unequivocal about the need to work together on every level as Europeans. It states:

Forging unity as Europeans ... has never been so vital nor so urgent. ... There is no clash between national and European interests. Our shared interests can only be served by standing and acting together. Only the combined weight of a true union has the potential to deliver security, prosperity and democracy to its citizens and make a positive difference in the world (Global Strategy 2016).

Indeed, one of the key features of the Global Strategy is that the EU plans to conduct its future external relations with more focus on its own region and neighborhood. The strategy is clear about the EU's foreign policy priorities, one of which is tackling the ongoing terrorist threat, particularly in terms of mainstreaming counter-terrorism in all of the EU's foreign policy initiatives.

Following the March 2016 Brussels attacks, a proposal for a new directive (COM (2015) 625 final) was approved at the European Parliament, criminalizing "preparatory acts" of terrorism. If approved after the final reading, this directive means that people who have traveled to Iraq or Syria to be trained in inciting terrorism could be arrested before the attack actually happens in Europe. The same is true for those discovered to be radicalizing people through 
propaganda over the internet. Such a strategy emphasizes European boundaries while bridging internal and external security dimensions because it criminalizes what is essentially the importation of anti-European ideas and actions into the European space.

\section{Formal Diplomacy}

Both formal and informal diplomacy play a similar role to intelligence sharing in terms of European boundaries. Both amplify the image of EU demoicracy with third countries in a way that is both tangible and inclusive. The more the EU speaks with one voice through its diplomacy, the more it strengthens European boundaries compared to national ones. In terms of formal diplomacy, after the January 2015 Paris attacks, the EEAS announced a new initiative to deploy security specialists to certain EEAS delegations in the Middle East, Gulf region, and North Africa who would be responsible for building an "anti-terror alliance" with their local Arab counterparts. This initiative involves increasing the numbers of EEAS personnel who speak Arabic, promoting cultural exchange with Muslims, and building working partnerships to combat Jihadi threats in third countries. The emphasis is on identifying good projects, best practices, and capacity building, rather than operational role that involves sharing intelligence.

Further, after the November 2015 attacks in Paris, Mogherini also emphasized the opportunity through formal diplomacy in the Vienna process. She said that, "Making the Vienna process work is the best answer we can give to terror - not the only one, but a crucial one" (EEAS November 16, 2015, p. 2). Even though the negotiations in Vienna have involved multiple countries with concerns over the Syrian civil war and the efforts to degrade ISIS, 
Mogherini was sure to highlight the EU's role in spearheading the creation of a special contact group led by Staffan de Mistura, UN Special Envoy. Upon arrival at the Foreign Affairs Council she said,

As you know the European Union has worked over these months since the summer to establish this contact group, insisting very much that all the relevant actors, regional and international actors, join their forces together to guarantee the fight against Da'esh and the defeat of Da'esh in Syria and at the same time ceasefire and a political transition for the country (Mogherini November 16, 2015).

Oftentimes once multilateral talks are underway, with many players at the table, the origins and impetus for the discussions are forgotten. However, these negotiations were launched in the first place as a result of EU efforts, giving the EU a presence on the international stage, not unlike its role in negotiating the nuclear deal with Iran.

On a more bilateral level, in December 2015, the EU adopted its position on counterterrorism as part of its renewed relationship with Morocco. In that agreement, the two actors agreed to work strongly together on stopping terrorist financing and foreign fighters (Statement by the EU December 14, 2015). Similarly, in the Counter-Terrorism Strategy with Syria \& Iraq, decided that same month, they launched new levels of cooperation to tackle foreign fighters, prevent terrorist financing, and deepen their bilateral dialogue to counter terrorist propaganda (Council Press Release December 14, 2015). In June 2016, EU discussions with Turkey ensued on how to set up a strong flow of communication to understand the reasons the Turkish border 
guards might have for sending people back to Europe. Around this time, further counterterrorism policies were initiated with Algeria and Egypt, and the goal was set to eventually put Libya at the top of the diplomatic agenda. All together, these initiatives indicated a significant growth in formal diplomacy and specific Political Dialogues on counter-terrorism with key countries, moving towards harder forms of enforcement.

\section{Informal Diplomacy}

The EU and 29 other countries have for five years participated in a Global CounterTerrorism Forum, which is a kind of transgovernmental network that determines best practices for dealing with various dimension of the terrorist threat. These best practices include everything from tackling foreign fighters to dealing with kidnapping for ransom to countering violent extremism (Global Counterterrorism Forum September 23, 2014). Through this forum, and other bilateral and multilateral venues the EU is quickly becoming a central player in global counter-terrorism, especially vis-à-vis its relationship to the US. Among other things, the EU provides funding for the Center of Excellence in Abu Dhabi focused on countering violent extremism, the Malta Institute, which trains judges in Benin, Chad, Mali, Niger, Cameroon, Senegal and Burkina Faso on how best to deal with terrorism cases, and the Global Community Engagement and Resilience Fund concentrated on local communities (Mogherini speech September 21, 2016).

Through informal diplomacy, the EEAS is pushing European-level policies further in light of the 2015 and 2016 attacks. For example, a new Commission initiative seeks to involve 
IT companies in tackling terrorism, and there are more ideas being discussed about how to prevent radicalization in the cyber realm. Governments are not the best actors to deal with this, but civil society organizations and private companies can often be more effective. Indeed, after the November 2015 attacks, Mogherini (November 26, 2015) said in a speech that, "foreign policy can no longer be the exclusive domain of diplomats and policy makers: foreign policy concerns us all." Thus, the EU, especially the EEAS, has been involved in a multitude of forums and informal deliberation with many actors, especially the United States. Oftentimes, the approach is more at the level of public diplomacy, including having EU officials appear at various events, to talk about how the EU is handling counter-terrorism, and its desire to be a leader in global solutions. After the Brussels attacks, Mogherini spoke alongside US Secretary of State John Kerry at the Global Coalition to Counter Da'esh. All of these wide ranging initiatives are designed to consolidate a European presence on the world's stage, to emphasize its legal personality, and form stronger partnerships with third countries. Informal diplomacy is inherently less prone to a hardening of political authority over time, compared to the other policy innovations. These types of approaches are more consistent with fostering an ideational space for crafting a European strategy that involves citizen participation in foreign policy.

All together, these policy innovations show the vast range and power of EU institutions to emphasize European boundaries precisely when security challenges get tough, and even over a short period of time. Much of this has happened with only brief or passing reference to the nationalistic blowback at the societal level in response to terrorism. But in this respect, it is almost always the case that EU officials have referred to the arguments of far-right parties Islamophobia and push for anti-immigration policies - as part of the problem, even as a by- 
product of the terrorist threat itself. In effect, they argue that by countering-terrorism effectively and strengthening European boundaries, the internal threat to these boundaries will also dissipate. The final section sums up these findings, and examines the extent to which these trends can be seen as legitimate.

\section{The Legitimacy of European Boundaries}

The EU has decided to take an active role in countering terrorism through its external relations. In launching intelligence sharing agreements, far-ranging strategies that bridge both internal and external security, and third-country partnerships and dialogues, the EU has strengthened its common boundaries. At the same time, certain groups within member states have reacted in entirely different ways. Far-right nationalists have gained traction in response to the attacks, and this has manifested as a backlash to the EU's foundational principles of inclusion and diversity. In the face of this, the EU has used crises as opportunities for policy innovation, and member states have supported this. Indeed, member states are always heavily involved in defining the terrorist threat and responding to it both at the national and European levels. At the same time, it must be recognized that there is a difference between making decisions to strengthen borders, and actually achieving this outcome. It may be some time before the measurable outcomes and successes of these strategies are known, but it is clear that the political will is present to make these decisions in the first place.

While it could be said that the EU does not yet have a strong enough or consistent territorial myth, as Vincent de Sala argues in this special issue, I would argue that the EU does 
actually have more ground to stand on when it comes to the broader notion of boundaries, which can be non-territorial too. As noted in the introduction to this article, processes similar to what we observe in the field of counter-terrorism are also playing out in other realms of the EU's external relations. From climate change to Brexit to Russian aggression, European boundaries and political authority are taking precedence over national ones, mostly with great efforts on the part of member states. Most recently, in reaction to the election of the unpredictable and autocratic Donald Trump as president in the United States, there have been numerous indications of an even deeper desire to emphasize European boundaries to ensure Europe's ability to act separately from the US going forward. The media focus on EU failures in times of crisis is often misleading and exaggerated (Cross and Ma 2015). Europe ultimately tends to pull together when times get tough. Indeed, without this core loyalty to the European project there is nothing really preventing the whole experiment from falling apart.

But how legitimate is this given that not everyone shares this loyalty, and these policies are adopted under emergency conditions? In terms of democratic input the question of legitimacy primarily relies on a close examination of processes of decision-making within the EEAS, member states, and other key institutions. I argue that input legitimacy is unproblematic in this case. Behind all of the policies adopted in the wake of the 2015 and 2016 attacks is a legal justification that is traceable back to democratic processes. Again, member states play a strong role in agreeing to policies in this area, especially since counter-terrorism involves issues integral to national sovereignty. In addition, the European Parliament has deliberated upon and approved even the more controversial policies, such as the PNR and the prohibition of "preparatory acts" of terrorism. Indeed, Kaunert, Léonard, and MacKenzie (2015) emphasize 
that the European Parliament's role has become significantly stronger in determining the external dimension of EU counter-terrorism since the 2009 Lisbon Treaty. Just because nationalist voices within some member states are stronger, does not mean that they should have a say in government. Input legitimacy is ultimately a political and institutional question about how member states determine their own foreign policies, and whether they seek to operate through the EU in certain areas. Many states have an accepted practice of deciding upon complex foreign policy strategies behind closed doors in light of the need to maintain secrecy in this area. This too is an accepted part of democratic process. As long as no far-right party controls the government of a member state, then just like in any group in opposition, they should have no expectation of seeing their views represented over others.

I would also argue that Europe's tendency to respond to certain types of crisis with more integration has a form of moral legitimacy in its own right. Recalling the EU's history and its founding purpose, the European Movement of the 1940s and 50s had a constitutional vision for Europe in which security and peace would be central. Embedded into the integration project from the start was the idea that member states would give up sovereignty to guard against the resurgence of strong forms of nationalism. This would prevent the violent and deadly wars of the past. Thus, the pattern of strengthening European boundaries for reasons of security also has a basis in output legitimacy. In effect, the creators of the EU's institutions foresaw a need to uphold a meaning of Europe defined against the dangers of nationalism. As the EU evolved, it became more and more accepted that individual member states would not and could not provide for their own security. Rather, this responsibility would be shared among member states. Terrorism in Europe goes hand-in-hand with precisely the kind of nationalism that has led to 
violence, the collapse of democracy, and vast insecurity in Europe's past. In light of this, there is often reference to universal norms for legitimate action: an attack on France is an attack on Europe and an attack on civilization itself. Thus, in light of Europe's current threat environment, which involves attacks on the EU's founding purpose from both the inside and outside, there is both a democratic and institutional justification for strengthening European boundaries.

\section{References}

Argomaniz, Javier, Oldrich Bures, and Christian Kaunert. 2015. “A decade of EU counterterrorism and intelligence: A critical assessment," Intelligence and National Security 30(2-3): 191-206.

Balzacq, Thierry (ed). 2011. Securitization Theory: How Security Problems Emerge and Dissolve. Preface. New York: Routledge.

Bellamy, Richard and Sandra Kröger. "Heterogeneity and the Demoicratic Rationale for Differentiated Integration"

Bicchi, Federica. 2007. European Foreign Policy making toward the Mediterranean. Houndmills: Palgrave.

Buzan, Barry, Ole Wæver, and Jaap De Wilde. 1998. Security: a new framework for analysis. Lynne Rienner Publishers.

Chebel d'Appollonia, A. and Reich, S., eds., 2008. Immigration, integration, and security: America and Europe in comparative perspective. Pittsburgh, PA: University of Pittsburgh Press.

Colman, N., 2006. "From Gulf war to Gulf war: years of security concern in immigration and asylum policies at EU level.” in: A. Baldaccini and E. Guild, eds. Terrorism and the 
foreigner: a decade of tension around the rule of law in Europe. Leiden: Martinus Nijhoff.

Council of the European Union. 2015. "Conclusions of the Council of the EU and of the Member States meeting within the Council on Counter-Terrorism," Press Release 848/15, November 20.

Council of the European Union. 2015. "Outcome of the Council Meeting, 3426 ${ }^{\text {th }}$ Council Meeting, Foreign Affairs,” Brussels, November 16 and 17.

Council of the European Union, 2015. "EU Passenger Name Record (PNR) directive: Council confirms agreement found with EP,” Press Release, December 4.

Council of the European Union. 2015. "Main Results: Foreign Affairs Council," November 16. http://www.consilium.europa.eu/en/meetings/fac/2015/11/16-17/

Council of the European Union. 2015. Press release from the European Council, "Council Conclusions on Iraq," December 14.

Council of the European Union. 2015. "Conclusions of the Council of the EU and of the Member States meeting within the Council on Counter-Terrorism," Press Release 848/15, November 20.

Council of the European Union. 2015. "Outcome of the Council Meeting, 3426 ${ }^{\text {th }}$ Council Meeting, Foreign Affairs," Brussels, November 16 and 17.

Cross, Mai'a K. Davis. 2011. Security Integration in Europe: How Knowledge-based Networks are Transforming the EU, Ann Arbor: University of Michigan Press.

Cross, Mai'a K. Davis. 2016. “The EU Global Strategy and diplomacy,” Contemporary Security Policy, 37(3): 402-413.

Cross, Mai'a K. Davis. 2017. The Politics of Crisis in Europe. New York: Cambridge University Press. 
Cross, Mai'a K. Davis and Ireneusz Pawel Karolewski (eds). 2016. Europe's Hybrid Foreign Policy: The Ukraine-Russia Crisis, Journal of Common Market Studies. Advance Online Publication.

Cross, Mai'a K. Davis and Xinru Ma. 2015. "EU Crises \& Integrational Panic: The Role of the Media." Journal of European Public Policy 22(8): 1053-1070.

"EU har lansert 239 antiterrortiltak," Aftenposten, January 16, 2015, URL: http://www.aftenposten.no/nyheter/uriks/EU-har-lansert-239-antiter- rortiltak-7864408.html cited in Strazzari and Stambøl 2015.

European External Action Service. 2016. “Counter-Terrorism." May 3. http://eeas.europa.eu/topics/counter-terrorism/411/counter-terrorism_en

European External Acton Service. 2015. "Speech by High Representative /Vice President of the European Commission and Head of the European Defence Agency Federica Mogherini at the EDA Annual Conference.” Brussels, November 16, 151116/03, p. 2.

European External Action Service. 2015. Statement by High Representative/Vice-President Federica Mogherini following her meeting with a delegation of the European Jewish Congress, Brussels, January 14.

150114_01_en http://www.eeas.europa.eu/statements-eeas/2015/150114_01_en.htm

European Union. 2016. “Shared Vision, Common Action: A Stronger Europe: A Global Strategy for the European Union's Foreign and Security Policy.” June.

"Exchange of views with Gilles de Kerchove, EU Counter-Terrorism Coordinator on the fight against terrorism and recent attacks in Member States." September 26, 2016.

"Fight against Terrorism News Alerts," European Parliament Audiovisual Services for Media, October 25, 2016. http://audiovisual.europarl.europa.eu/Page.aspx?id=2755 
Foreign Affairs Council, November 16-17, 2015.

The Global Counterterrorism Forum, Fifth Ministerial Plenary, 23 September 2014, New York.

Holehouse, Matthew and Ben Riley Smith. 2016. "EU leaders consider two-year suspension of Schengen rules." The Telegraph, January 22.

Huysmans, J., 2006. The politics of insecurity: fear, migration and asylum in the EU. London: Routledge.

Kaunert, Christian, Sarah Léonard, and Alex MacKenzie. 2015. "The European Parliament in the external dimension of EU counter-terrorism: more actorness, accountability and oversight 10 years on?." Intelligence and National Security 30(2-3): 357-376.

Léonard, Sarah. 2010. "EU border security and migration into the European Union: FRONTEX and securitisation through practices." European Security 19(2): 231-254.

Mitrany, David. A working peace system. Chicago: Quadrangle Books, 1966.

Mogherini, Federica. 2016. Speech by High Representative/Vice-President at this year's Global Counter Terrorism Forum Ministerial Meeting. New York, September 21.

Mogherini, Federica. 2015. Remarks by High Representative/Vice-President upon arrival at the Foreign Affairs Council. November 16.

Mogherini, Federica. Speech by High Representative/Vice-President at this Year's Global Counter Terrorism Forum Ministerial Meeting. New York, 21 September 2016

Mogherini interview with Christiane Amanpour on CNN, January 22, 2015.

Mogherini, Federica. 2015. Speech by High Representative/Vice-President, "The EU InternalExternal Security Nexus: Terrorism as an example of the necessary link between different dimensions of action EU Global Strategy," Conference organised by EUISS and Real Institute Elcano, Barcelona. November 26. 
Monar, Jörg. 2015. "The EU as an international counter-terrorism actor: Progress and constraints." Intelligence and National Security 30(2-3): 333-356.

Mueller, John E. 2006. Overblown: How politicians and the terrorism industry inflate national security threats, and why we believe them. New York: Simon and Schuster.

Natorski, Michal and Karolina Pomorska. 2016. "Trust and Decision-making in Times of Crisis: The EU's Response to the Events in Ukraine." Journal of Common Market Studies. Advance Online Publication.

Nicolaïdis, Kalypso and Juri Viehoff. "Just Boundaries for Demoicrats.”

Orenstein, Mitchell A. and R. Daniel Kelemen. 2016. "Trojan Horses in EU Foreign Policy." Journal of Common Market Studies. Advance Online Publication.

Palmer, John. 2013. "The rise of far right parties across Europe is a chilling echo of the 1930s." The Guardian, Opinion, November 15.

Schilde, Kaija. 2016. “European Military Capabilities: Enablers and Constraints on EU Power?” Journal of Common Market Studies. Advance Online Publication.

Tocci, Nathalie. "The Making of the EU Global Strategy." Contemporary Security Policy 37(3): 461-472

Torney, Diarmuid and Mai'a K. Davis Cross. Forthcoming. "Environmental and Climate Diplomacy." In Camilla Adelle, Katja Biedenkopf, and Diarmuid Torney (eds) The External Dimension of European Union Environmental Policy: Rules, Regulation and Governance Beyond Borders, Houndmills: Palgrave.

Schmidt, Vivien A. 2013. "Democracy and legitimacy in the European Union revisited: input, output and 'throughput'." Political Studies 61(1): 2-22.

Statement by the European Union. 2015. "Thirteenth Meeting of the EU-Morocco Association 
Council.” Brussels, December 14.

Strazzari, Francesco and Eva Magdalena Stambøl. 2015. "We Saw it Coming: Jihadist Terrorism, Challenges for the European Union.” Norwegian Institute of International Affairs (NUPI) Policy Brief 13/2015.

Stritzel, Holger. 2007. "Towards a theory of securitization: Copenhagen and beyond." European Journal of International Relations 13(3): 357-383.

Wæver, Ole. 2011. "Politics, security, theory.” Security Dialogue 42(4-5): 465-480.

Taurec, Rita. 2006. "Securitization theory and securitization studies." Journal of International Relations and Development 9(1): 53-61.

Vries, Gijs de. 2016. "The European response to terrorism.” ACI Security Summit, Brussels, November 23.

Zielonka, Jan. "The remaking of the EU's borders and the images of European architecture." 